\title{
Arctic Climate and Water Change: Model and Observation Relevance for Assessment and Adaptation
}

\author{
Arvid Bring • Georgia Destouni
}

Received: 15 February 2013/Accepted: 14 November 2013/Published online: 24 December 2013

(C) The Author(s) 2013. This article is published with open access at Springerlink.com

\begin{abstract}
The Arctic is subject to growing economic and political interest. Meanwhile, its climate and water systems are in rapid transformation. In this paper, we review and extend a set of studies on climate model results, hydro-climatic change, and hydrological monitoring systems. Results indicate that general circulation model (GCM) projections of drainage basin temperature and precipitation have improved between two model generations. However, some inaccuracies remain for precipitation projections. When considering geographical priorities for monitoring or adaptation efforts, our results indicate that future projections by GCMs and recent observations diverge regarding the basins where temperature and precipitation changes currently are the most pronounced and where they will be so in the future. Regarding late twentieth-century discharge changes in major Arctic rivers, data generally show excess of water relative to precipitation changes. This indicates a possible contribution to sea-level rise of river water that was previously stored in permafrost or groundwater. The river contribution to the increasing Arctic Ocean freshwater inflow is similar in magnitude to the separate contribution from glaciers, which underlines the importance of considering all possible sources of freshwater when assessing sea-level change. We further investigate monitoring systems and find a lack of harmonized water chemistry data, which limits the ability to understand the origin and transport of nutrients, carbon and sediment to the sea. To provide adequate information for research and policy, Arctic hydrological and hydrochemical monitoring needs to be extended, better integrated and made more accessible. Further water-focused data and modeling efforts are required to resolve the source of excess discharge in Arctic rivers. Finally, improvements in climate model parameterizations are needed, in particular for precipitation projections.
\end{abstract}

Keywords Hydrology $\cdot$ Monitoring $\cdot$ Arctic $\cdot$ Climate change $\cdot$ Adaptation

\footnotetext{
A. Bring $(\bowtie) \cdot$ G. Destouni

Department of Physical Geography and Quaternary Geology, Stockholm University, 10691 Stockholm, Sweden

e-mail: arvid.bring@natgeo.su.se
}

A. Bring · G. Destouni

Bert Bolin Centre for Climate Research, Stockholm University, Stockholm, Sweden 


\section{Introduction}

A multitude of global changes, including climate change, are currently transforming the Earth system. This is clearly evident in the Arctic, where surface temperatures over the last half-century have increased at a rate of $50 \%$ higher than the Northern Hemisphere average (McBean et al. 2005), and where future climate change is expected to be the most pronounced (Kattsov et al. 2005). Coupled to the changes in the physical environment, the Arctic is also increasingly becoming a focal point of economic and geopolitical interest.

These transformations present a considerable challenge. The critical role of the Arctic in the global climate system implies that Arctic changes will have far-reaching consequences for, and feedbacks to, the entire Earth system (McGuire et al. 2006). For the Arctic region, in turn, global-scale changes, regional and local environmental changes, and geopolitical and economic changes all contribute to the societal need for adaptation, and to the need for information and monitoring to guide that adaptation (Azcárate et al. 2013).

As an integrating, propagating and regulating factor, water plays a central role in the changing Arctic and the wider global climate system. It is a shared component in the most recognized Arctic indications of global change. These indications include rapidly diminishing extent of sea ice (Comiso et al. 2008; Stroeve et al. 2012a), increased mass loss from glaciers (Kaser et al. 2006; Gardner et al. 2011), increasing river flows (Peterson et al. 2002, 2006; McClelland et al. 2006; Shiklomanov and Lammers 2009; Overeem and Syvitski 2010) and increasing groundwater contribution to those flows (Smith et al. 2007), permafrost degradation (Hinzman et al. 2005; White et al. 2007; Lyon and Destouni 2010; Brutsaert and Hiyama 2012), ecosystem regime shifts (Smol et al. 2005; Karlsson et al. 2011), and shorter extent of snow cover season (Brown et al. 2010; Callaghan et al. 2011). All these constitute water changes, some of which are fundamentally caused by the overarching driving force of climate change. Some water changes, however, may also arise due to direct human interference, for example, through freshwater abstractions for or losses by food and energy production (Destouni et al. 2013), or clear-cutting of forests (Seitz et al. 2013). Whether the driving forces are local or global, water changes require local adaptation, for example, of infrastructure for energy, transport and buildings, of agricultural and forestry practices, and of measures for food and water security (Nilsson et al. 2013).

A primary information basis for projections of large-scale climate change is the ensemble of general circulation models (GCMs) that underlie the assessment reports of the Intergovernmental Panel on Climate Change (IPCC). The two most recent full reports are the Third Assessment Report (TAR; 2001) and the Fourth Assessment Report (AR4; 2007). The fifth IPCC report (AR5) is currently being released, with the first working group contribution published in September 2013.

The performance of GCMs in the Arctic has been the subject of extensive discussion. Assessments of TAR and AR4 model performance have shown improvements between successive generations of models, but also indicated that significant shortcomings remain in simulating observed climate parameters (Christensen et al. 2007). There have been several assessments of simulations of sea ice processes (Zhang and Walsh 2006; Overland and Wang 2007; Stroeve et al. 2007; Eisenman et al. 2007; Holland et al. 2010; Stroeve et al. 2012b), the surface radiation budget (Sorteberg et al. 2007; Boé et al. 2009) and surface temperature (Lui et al. 2008) over the Arctic Ocean, but fewer studies of GCM performance related to the continental part of the Arctic hydrological cycle on drainage basin scales. Kattsov et al. (2007) analyzed the output of the AR4 model ensemble for four major basins in the Pan-Arctic Drainage Region (PADB), and Roesch (2006) evaluated 
AR4 simulations of snow cover. Holland et al. (2007) investigated ten AR4 GCMs to estimate change in the freshwater budget of the Arctic Ocean, including pan-Arctic scale runoff, and Rawlins et al. (2010) used the same GCMs combined with reanalysis and observational data in a pan-Arctic analysis of Arctic hydrological cycle intensification.

However, no basin-wise investigation and comparison of GCM results between the TAR and AR4 has been performed for a larger set of basins within the PADB, and no benchmark of AR4 GCM performance over such a set of basins exists for comparison with the AR5 set of models. An evaluation of GCM projections in a hydrological context is therefore motivated and would inform both the parameterization of land surface schemes in GCMs, and the developers and end users of regional climate model and their results. In the end, it would benefit anyone whose decisions are influenced by the reliability of water change projections. Previous investigations into GCM agreement with hydro-climatic observations, for other regions than the Arctic, have for instance revealed that GCM projections of evapotranspiration may be more uncertain than originally thought (Mueller et al. 2011).

Even if projections of the atmospheric components of the Arctic hydrological cycle (AHC) were satisfactory, it is the translation of changes in these components to water system changes in the landscape that is central to adaptation. Spatial planning, infrastructure dimensioning and water resources planning all depend on reliable understanding and projection of changes to water availability, river flows, flood and drought frequencies. Therefore, considerable efforts have been directed toward understanding the complex changes in Arctic surface and groundwater systems in the recent decades. Several integrative system assessments (e.g., Vörösmarty et al. 2001; Serreze et al. 2006; Slater et al. 2007; Rawlins et al. 2009, 2010), together with numerous site-specific studies, have greatly improved knowledge of the AHC. Nevertheless, a number of inconsistencies, gaps in understanding and open questions still remain (Arctic-HYDRA consortium 2010). Definite understanding of several AHC components, and how they are linked, is still lacking.

To remediate these shortcomings, and advance the development of GCMs and our understanding of hydro-climatic change, relevant and accessible observations have a central role. Advances in theories, models, scenarios and projections fundamentally rely on observational data. The importance of data and observation systems has also recently been emphasized at intergovernmental summits (GEO 2010) and recognized as one of five "grand challenges" for Earth system science and science policy over the next decade (Reid et al. 2010; ICSU 2010). Constraints in the availability of data limit the ability to evaluate projections, climate model parameterizations, and hypothesized changes and functions of environmental systems. There is therefore a strong link between the output of GCMs, observation systems and, in the end, the ability of society to plan for and adapt to hydrological changes that affect industry, agriculture and water resource availability.

A primary class of environmental data required to assess AHC change is river discharge. In addition, sediment and water chemistry data are needed to estimate the waterborne mass fluxes of constituents in global biogeochemical cycles, such as carbon, nitrogen and phosphorus. Besides their role in the global cycles, these elements are also directly related to societal impacts through their links to eutrophication (Darracq et al. 2008), aquatic habitat and ecosystem changes (Palmer et al. 2009), and feedbacks to climate change (Lyon et al. 2010). The collection of such hydrological and hydrochemical data is normally conducted through continuous monitoring programs by various government agencies. However, in many countries, hydrological observation systems have been in decline during recent decades. The extent of monitoring generally peaked around 1980, after the significant increases in monitoring efforts during the International Hydrological Decade 
1965-1974. Since then, budget constraints and failure to maintain existing systems have resulted in a general decline in monitoring, something that has been reported in several studies (Brown 2002; Fekete and Vörösmarty 2002; Maurer 2003; Hannerz 2008; FAO 2009).

The global trend of declining discharge monitoring is also evident in the Arctic (Lammers et al. 2001; Shiklomanov et al. 2002; Hinzman et al. 2005; Walsh et al. 2005, Arctic-HYDRA consortium 2010). The particular situation in the Arctic has received relatively much attention in the scientific community, partly due to the rapid changes and the general scientific interest in the region. Also, the accessibility to discharge data has been improved more in the Arctic than in many other parts of the world. These improvements are mostly due to a few concentrated international collaborations, several of which were coordinated from the University of New Hampshire. Nevertheless, some of these efforts are now several years in the past, and the accessibility to recent discharge data that they initially provided has not always been sustained.

In contrast to the situation for discharge monitoring, a clear picture of the status of water chemistry data has been lacking. Previous efforts have tried to assess the state of affairs for certain parameters (e.g., Holmes et al. 2000, 2002; Raymond et al. 2007) and estimated the quality of existing data (Zhulidov et al. 2000, 2003; Holmes et al. 2001). Although specific data sets have been made accessible for parts of the PADB (e.g., Holmes et al. 2000; Holmes and Peterson 2002), and in at least one case for the wider PADB (McClelland et al. 2008; data at http://www.arcticgreatrivers.org), no international repository and data host exists for all accessible Arctic water chemistry data. Neither has any initiative yet been launched to develop a common set of indicators, such as the Millennium Development Goals-related UN Federated Water Monitoring System (FWMS) and its Key Water Indicators Portal (KWIP).

The decline in station numbers and the lack of integrated hydrological and hydrochemical information, together with the grand challenge of improving Earth observation systems, constitute an imperative to develop Arctic hydrological monitoring networks and to ensure their relevance under conditions of climate change. This would enable improvements in both GCMs and hydro-climatic change understanding.

The importance of the continental water system in Arctic and global change means that the hydrological drainage basin is a fundamental and relevant spatial scale unit, both for water management and adaptation, and for basic research (Pahl-Wostl 2007; UNECE 2009). In this paper, we therefore survey and review several components required to provide reliable water information, and to do this consistently at drainage basin scales. Basin-scale water information also has ensuing applications in understanding coupled changes across other terrestrial, atmospheric and marine systems (e.g., Karlsson et al. 2011).

This review paper addresses the following three overarching topics:

- The reliability of GCM projections on the scale of main Arctic river basins, as base information for understanding and for societal adaptation to Arctic climate and water change;

- The recently observed changes to water flow and water budgets in the Arctic hydrological cycle, and their potential consequences for both societal adaptation and freshwater input to the Arctic Ocean; and

- The representativeness, accessibility and relevance of hydrological and hydrochemical observation systems for assessing changes to water, sediment and hydrochemical fluxes in the Arctic hydrological cycle. 
Furthermore, an ensuing question that relates to all of the above is: What critical gaps and key limitations exist in each of these topics, and is there a basis to rationally prioritize how to address those limitations by hydrological monitoring development?

We here synthesize information on these topics by integrating a set of previous studies of Arctic hydro-climatic change (Bring and Destouni 2009, 2011, 2013; Dyurgerov et al. 2010). We also extend the results from these reports with an additional analysis of GCM projection performance for major Arctic hydrological basins.

\section{Methods Summary}

In the following, we summarize the data and methods used in the synthesized previous studies (Bring and Destouni 2009, 2011, 2013; Dyurgerov et al. 2010) and the novel extensions in this paper. For a more detailed account of the methods used in the previous studies, we refer to the aforementioned publications. We have in this review re-evaluated some of the previous results by correcting observed precipitation data sets for gauge undercatch and orographic effects. To this end, we used two global data sets by Adam and Lettenmaier (2003) and Adam et al. (2006). However, as precipitation corrections in other cases have been known to result in overestimated precipitation (Mächel et al. 2012), we here treat the originally reported observations and the fully corrected values as two ends of a range. As we have no knowledge of the probability distribution of values within this range, we treat the middle of the range (i.e., the average of the original and the corrected values) as the best estimate of observed precipitation.

In general, the hydrological drainage basin has been the fundamental basis for the investigations in this study. The drainage basin constitutes a physically consistent boundary for closing the flow balance of water and the mass balances of constituents transported by water, which makes it a relevant scale for addressing both science and management problems.

In the paper, we focus primarily on the 14 largest watersheds in the PADB. Each of them is at least $200,000 \mathrm{~km}^{2}$ in size, and their combined drainage covers 13.8 million $\mathrm{km}^{2}$ (green and blue basins in the map of the study area in Fig. 1). These 14 basins are sufficiently large to allow an analysis of GCM data. Figure 2 shows the characteristic temperature and precipitation conditions, and recent observed changes for those parameters, in the 14 major basins.

The analyses in the surveyed and synthesized publications concern slightly varying time periods and, in general, involve comparisons of time periods of different lengths. Although it would be desirable to always compare the same time periods, the differences between the surveyed publications are relatively small in this regard. Several publications also study the longest possible period since 1990 for which there are data available, and compare that period with the reference of 1961-1990. Since the recent period from 1991 to (near-) present time is considerably shorter than the 30 years of the climatological reference period 1961-1990, we here regard the changes from the latter to the recent period as deviations from the referencetime climate and not necessarily as climate change. With inter-annual variability of various magnitudes for different parameters and basins, the future 30-year climate starting from 1991 may differ from these shorter-term deviations.

\subsection{GCM Projections Across Arctic Basins}

We first examine two successive generations of GCMs, which form the basis for the two latest available full IPCC assessment reports, the TAR and AR4. We here compare the 

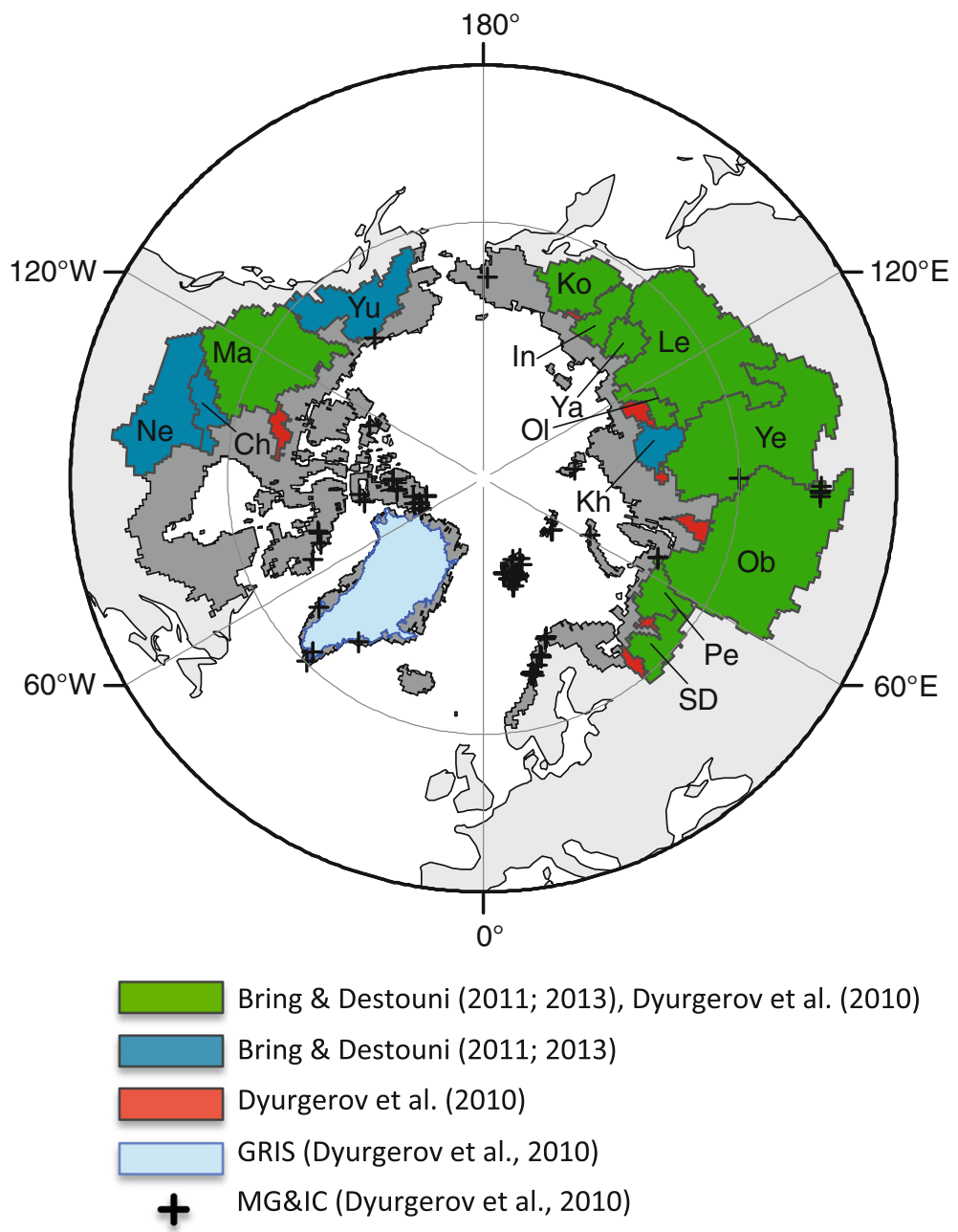

Fig. 1 Map indicating studied areas of the PADB. Bring and Destouni (2009) includes all areas within the PADB, demarcated by the combined area of all colored basins and the dark gray area. MG\&IC: Mountain glaciers and ice caps; GRIS: Greenland ice sheet. Basin names are abbreviated as Ne Nelson, $C h$ Churchill, Ma Mackenzie, Ko Kolyma, Kh Khatanga, Ol Olenek, Le Lena, Ya Yana, In Indigirka, Ye Yenisey, SD Severnaya Dvina, $P e$ Pechora and $Y u$ Yukon. Lambert azimuthal equal-area projection; approximate scale $1: 150,000,000$. Spatial resolution of basin outlines is $0.5^{\circ}$

14-basin average values of TAR and AR4 temperature and precipitation (downloaded from http://www.ipcc-data.ch; included models summarized in Table 1) with observations (CRU TS 2.1, Mitchell and Jones 2005) for the periods 1961-1990, 1991-2002 (observations) and projections for 2010-2039 (GCMs).

We then investigate in more detail the AR4 model results for the historical 20C3M scenario and the period 1961-1990, by calculating three separate measures of model performance: mean absolute error (MAE), mean bias error (MBE) and an index of model performance $\left(d_{r}\right)$. For a given drainage basin, the MAE is defined as 
Fig. 2 Climate characteristics of the 14 major Arctic basins. The top panel shows average annual temperature; the bottom one shows annual average precipitation, for the periods 1961-1990 and 1991-2009. Data from CRU (Harris et al. 2013) and Willmott \& Matsuura (http://climate.geog. udel.edu/ climate). Precipitation values are averages of original data and data with orographic and undercatch corrections (Adam and Lettenmaier 2003; Adam et al. 2006)
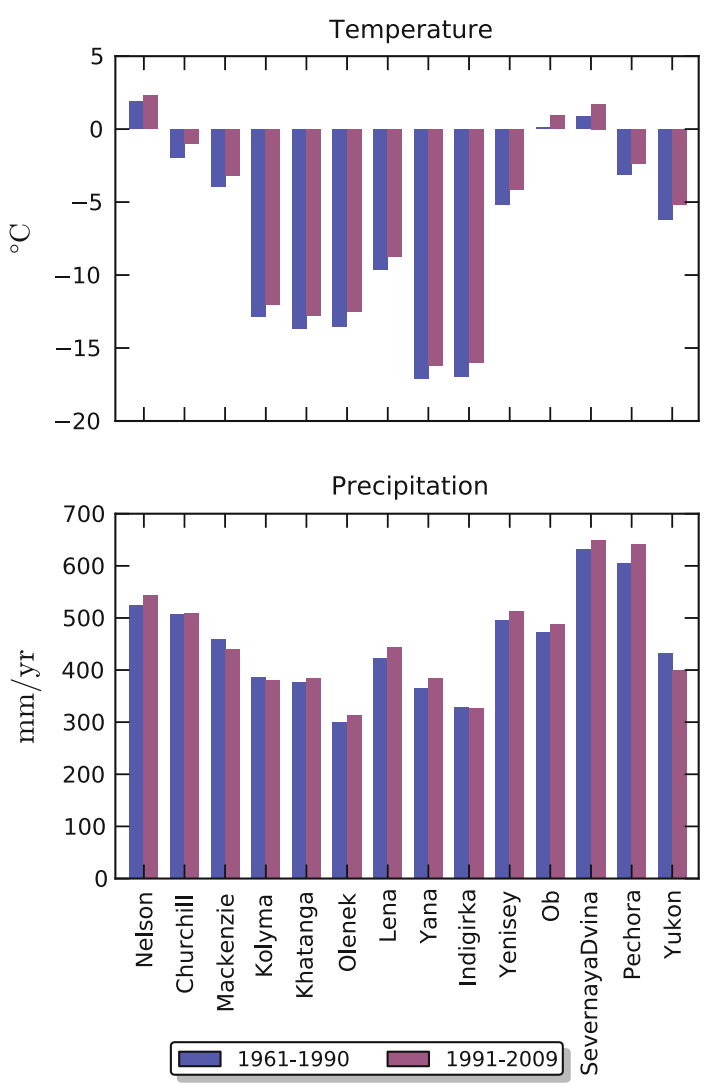

MAE $=\frac{1}{W} \sum_{i=1}^{n} w_{i}\left|e_{i}\right|$

where $e_{i}=P_{i}-O_{i}$ is the difference between the model-projected value $P_{i}$ and the observed value $O_{i}$ for all cells $i=1,2, \ldots, n$ within the basin. The term $w_{i}$ denotes the area-relative weight of each cell and $W$ the sum of these weights. Similarly, the MBE describes the area-weighted sum of the deviations of model projections from observations, but retains the signs of the differences:

$$
\mathrm{MBE}=\frac{1}{W} \sum_{i=1}^{n} w_{i} e_{i}
$$

In comparing models across several drainage basins or for several parameters, a dimensionless index of model performance can complement the MAE and MBE, which are both defined in the units of the studied model parameter. We therefore also calculate such a dimensionless measure: the refined index of model performance $d_{r}$, with values on a unitless scale from -1 to 1 (worst to best). The $d_{r}$ index is comprehensively defined in Willmott et al. (2012), and in their words, "[i]t indicates the sum of the magnitudes of the differences between the model-predicted and observed deviations about the observed mean relative to the sum of the magnitudes of the perfect model $\left(P_{i}=O_{i}\right.$, for all $\left.i\right)$ and observed deviations about the observed mean." 
Table 1 GCMs included in the analysis

\begin{tabular}{ll}
\hline TAR models & AR4 models \\
\hline CCCma & BCM2 \\
CSIRO & CGHR \\
ECHAM4 & CNCM3 \\
GFDL99 & CSMK3 \\
HADCM3 & ECHOG \\
NIES99 & FGOALS \\
& GFCM20 \\
& GFCM21 \\
& GIAOM \\
& GIER \\
& HADCM3 \\
& HADGEM \\
& INCM3 \\
& IPCM4 \\
& MIHR \\
& MIMR \\
& MPEH5 \\
& MRCGCM \\
& NCCCSM \\
NCPCM \\
\hline
\end{tabular}

Note that not all models have data for all scenarios and parameters investigated

For the analysis of MAE, MBE and $d_{r}$, we use the mean of the CRU TS 3.1 (Harris et al. 2013) and Willmott \& Matsuura 3.1 data sets (http://climate.geog.udel.edu/ climate) as a benchmark against which to evaluate GCM output. By averaging two separate data sets, our confidence in the reliability of the precipitation estimates increases, as different data sets use slightly different approaches to calculate the same estimate.

Climate projections are critical to adaptation planning, for example, for long-term planning of infrastructure, power production and agriculture. We therefore test whether these projections agree with the observations of recent deviations with regard to which Arctic drainage basins will be most affected by climate change. The aim is to investigate whether a set of highly divergent future climate projections, together with recent observations of climate deviations, can form a consistent basis for prioritizing monitoring. Under limited resources, one either has to rely on some degree of certainty in the distribution of future changes and prioritize monitoring based on this distribution, or try to harmonize the different possible bases for rational monitoring prioritization that may arise from uncertain change projections.

In order to include as wide a spectrum of future climate change as possible over the next half-century, we formulate for this analysis two alternate final stages of possible climates. We select the five warmest or wettest models from the most severe IPCC Special Report on Emission Scenarios (SRES) scenario (A2), and the five coldest or driest models from the least severe scenario (B1). For details on the procedure and the selected models, we refer to Bring and Destouni (2013). For these two cases, we analyze the relative distribution of projected climate change severity across the 14 largest Arctic drainage basins and compare this distribution with recent observed deviations from the 1961 to 1990 climate. We emphasize here that, in absolute terms, we do expect divergence between the scenarios, 
and between each scenario and observations. However, in terms of the geographical distribution of relative change or deviation intensity, divergence is not necessarily expected; if such divergence in relative intensity prevails, it presents a main challenge for geographical monitoring prioritization, as discussed further in Sect. 6.3.

\subsection{Arctic Hydro-Climatic Change}

Precipitation output from GCMs is used to further model other hydro-climatic changes, most importantly runoff changes, at regional and finer scales. The usefulness of precipitation projections for adaptation planning, such as dimensioning of infrastructure and drainage systems, depends on this modeling and understanding of how the precipitation changes are (and have previously) transferred to runoff and other hydro-climatic changes in the landscape. We therefore here investigate how recently observed precipitation deviation has related to runoff deviation for 13 major basins where runoff data are accessible for 1961-1990 and 1991-2002, and compare these data on runoff deviation with corresponding observations of precipitation deviation from the CRU TS 2.1 database.

To gain a more comprehensive understanding of total freshwater flux changes in the Arctic system, we also perform an integrated assessment of freshwater inflow from both rivers and glaciers to the Arctic Ocean. Separation of the freshwater flux contributions from rivers and glaciers is here possible because the glaciated area of the major Arctic river basins is very small. Instead, glaciers and ice caps mostly contribute their melt water directly to the coast or through smaller watersheds. For the river component in this analysis, we therefore consider only major basins with negligible glacier area that drain to the proper Arctic Ocean with a discharge of at least $10 \mathrm{~km}^{3} /$ year. This drainage is a subset of the whole PADB and includes 17 basins, of which 11 (green basins in Fig. 1) are in common with the 14 major basins (green and blue basins in Fig. 1) in the GCM comparison discussed above, and the remainder are additional smaller river basins (red basins in Fig. 1). We specifically investigate the periods 1961-1992 and 1993-2006, with the period break coinciding with a marked increase in glacier mass loss. We combined discharge data from the R-ArcticNET (Lammers et al. 2001), ArcticRIMS (http://rims.unh. edu) and Water Survey of Canada HYDAT (Environment Canada 2004) databases. Glacier data consist of data on annual direct mass balance observations carried out for mountain glaciers and ice caps (MG\&IC; marked with crosses in Fig. 1; Dyurgerov and Meier 2005; Glazovsky and Macheret 2006; Fluctuations of Glaciers (FoG) 2008), and of several recent modeling studies for the Greenland ice sheet (GRIS; light blue in Fig. 1; Rignot et al. 2008; Hanna et al. 2008, 2009; Box et al. 2006; Mernild et al. 2009).

\subsection{Pan-Arctic Drainage Basin Monitoring}

Observations of discharge on various scales allow testing of water budgets, both for different landscape types and for the land surface area in general, which is useful in evaluating model assumptions and parameterizations. Water chemistry observations give information on upstream sources, sinks and hydrological transport pathways of biogeochemical constituents, and their changes. We therefore also synthesize and evaluate all accessible discharge and water chemistry data for the PADB. The extent of accessible data is presented in map form, illustrating the maximum length of time series and latest data year for the PADB. We further summarize the characteristics of monitored and unmonitored areas in North America, Europe and Asia and compare the differences between them. 
This synthesis shows whether the properties of areas that are monitored are representative of the unmonitored areas. This question is important, considering that extrapolation from monitored to unmonitored areas will always be needed to some degree.

\section{Results for GCM Projections Across Arctic Basins}

Figure 3 illustrates GCM projections and Climatic Research Unit (CRU) observations for the 14 major Arctic drainage basins (green and blue basins in Fig. 1; adapted from Bring and Destouni 2011). Temperature projections are compatible with observed deviations during the late twentieth and early twenty-first century, both for the TAR and AR4, while precipitation projections indicate an increase that is hitherto not evident in observations. The absolute GCM results compare well with the observations for temperature, but the models generally overestimate precipitation. However, while the difference between temperature projections and observations has increased between the TAR and AR4 model ensembles, precipitation projections have come closer to observations. Generally, GCM projections for temperature and precipitation have become more precise in the AR4 ensemble, as the models in AR4 converge more closely on the mean than do the TAR ensemble models.

Results from the error and performance analysis of the AR4 GCMs over the 14 largest Arctic watersheds indicate that there is a large spread in error and relative performance between the models used in the AR4 (Fig. 4). Although the inter-model variation in MAE is similar for temperature and precipitation, the difference between the systematic overestimation of precipitation, evident in the above-zero MBE for all models but one, and the relatively smaller systematic underestimation of temperature, evident in MBEs closer to zero, mean that the model performance index is less variable and, for most models, better for temperature than for precipitation.

For some basins, and for the pan-Arctic in general, an above-average model performance in temperature simulation does not correlate particularly strongly with performance in simulating precipitation (negative rank correlations for MAE and $d_{r}$; Table 2). This implies that choosing a "best" climate model for the Arctic or any of its major drainage
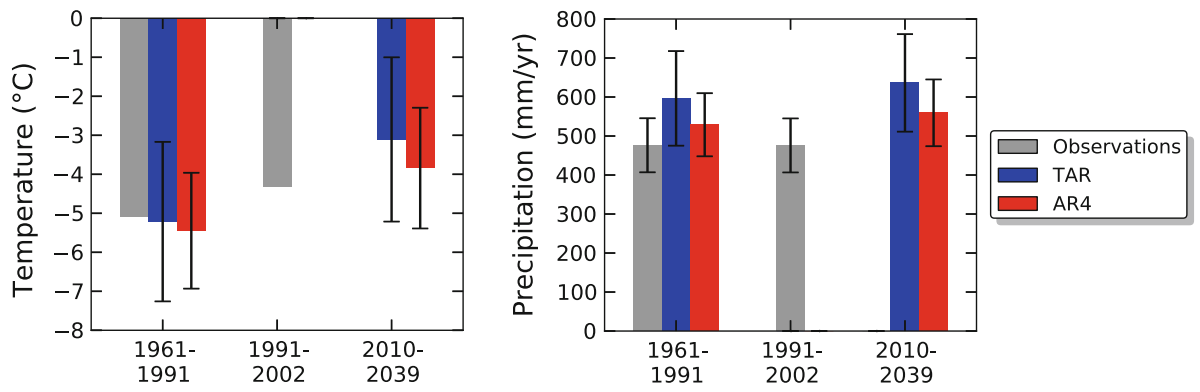

Fig. 3 Temperature (left) and precipitation (right) values for 1961-1990 and 1991-2002 for observations and for 1961-1990 and 2010-2039 for GCM projections across 14 major Arctic basins. Error bars for GCM projections indicate one standard deviation of different GCM results from the model ensemble mean. Error bars for precipitation observations indicate upper and lower estimates, corresponding to uncorrected and bias-corrected values, respectively 
Fig. 4 Mean absolute error (MAE; top panel), mean bias error (MBE; middle panel) and model performance index $\left(d_{r}\right.$; bottom panel) for 14 GCMs across the PADB for 1961-1990

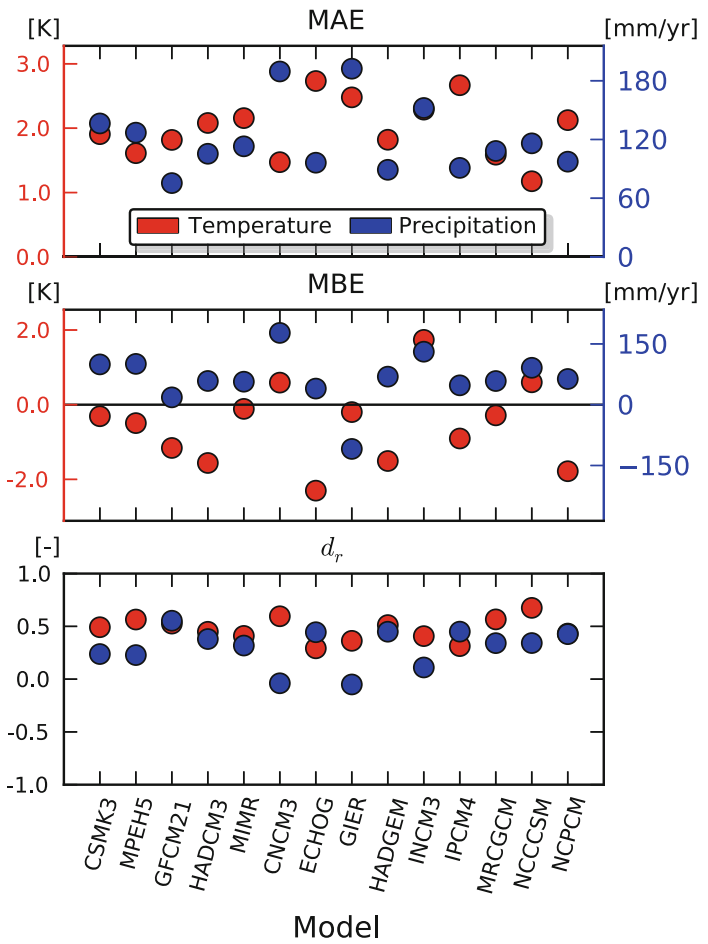

Table 2 Spearman's rank correlation coefficient $\rho$ between the pan-Arctic temperature and precipitation values of MAE, MBE and $d_{r}$

\begin{tabular}{llll}
\hline & MAE & MBE & $d_{r}$ \\
\hline$\rho$ & -0.13 & 0.41 & -0.13 \\
\hline
\end{tabular}

basins is difficult if one wants to have consistently good model performance for both of these parameters.

Model performance also varies considerably between the studied basins. The large Mackenzie and Yenisey basins exhibit consistently good $d_{r}$ values for temperature, while the $d_{r}$ of some models is considerably smaller for the Ob and Lena basins (not shown). In contrast, temperature $d_{r}$ values for the relatively smaller and neighboring basins of Pechora and Severnaya Dvina are poor for most models, indicating difficulties with temperature simulations west of the Ural Mountains. This may be due to the relatively smaller size of these basins, or the presence of natural low-frequency variation in the region (Hurrell and van Loon 1997). Precipitation $d_{r}$ values are overall lower, with the lowest values for the smaller Olenek and Severnaya Dvina basins, followed by the medium-sized Yukon basin, and the highest for the large Ob, medium-sized Nelson and small Khatanga basins.

Furthermore, results from an analysis of bases for prioritization monitoring under conditions of climate change (Bring and Destouni 2013) indicate that the basins with the highest recently observed deviations of temperature and precipitation are not the same basins that have the highest projected changes in future climate (rank correlations of basin orders are close to zero, or negative; Table 3). Therefore, prioritizing monitoring to basins 
Table 3 Spearman's correlation of GCM-projected climate change ranking with observed climate change ranking

\begin{tabular}{lr}
\hline Scenario & \multicolumn{1}{c}{$\rho$} \\
\hline Temperature & \\
Cool B1 & 0.01 \\
Hot A2 & -0.03 \\
Precipitation & \\
Dry B1 & -0.13 \\
Wet A2 & -0.19 \\
\hline
\end{tabular}
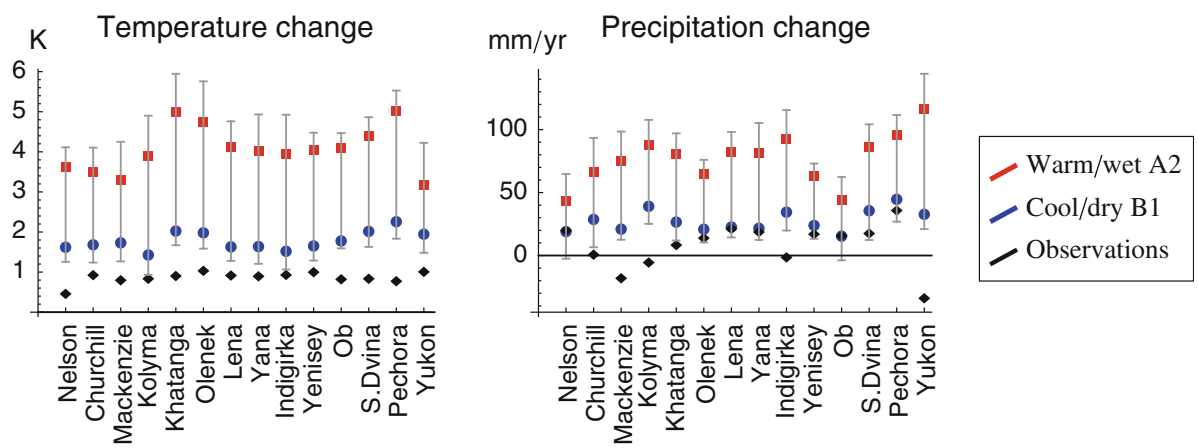

Fig. 5 Changes to temperature (left) and precipitation (right) from 1961-1990 to 1991-2009 for observations and to 2040-2069 for GCM projections across 14 major Arctic basins. Error bars indicate the range of different GCM results for both scenarios for each basin. Top ends of error bars extend one standard deviation of model means from the A2 scenario ensemble mean, and bottom ends extend one standard deviation of model means from the B1 scenario ensemble mean

with the strongest observed climate deviations is not reconcilable with prioritizing basins with greatest anticipated future climate change. In this analysis, the question is not whether models are able to reproduce observations, but whether the most (least) severe observed deviations occur in the same places as the projected future most (least) severe changes. To bring observed deviations in line with projections, continued increases are generally needed but, for precipitation, the direction of deviations must in several cases be reversed (Fig. 5). With ongoing climate change, continued increases in the same direction are naturally expected, as observations and projections concern different time periods in this analysis. Developing monitoring to capture such monotonous changes in magnitude is then one possible strategy. However, the disagreement in relative severity across basins between observations and GCM projections implies that alternative monitoring prioritization considerations are also possible and rational, as discussed further in Sect. 6.3.

\section{Results for Arctic Hydro-Climatic Change}

In Bring and Destouni (2011), we have compared precipitation and discharge deviations from the 1961 to 1990 climate average for the 14 major Arctic basins (green and blue basins in Fig. 1). A key result from that analysis is that the discharge deviation relations to the corresponding deviations in precipitation vary widely for the major basins in the PADB (Table 4). The majority of basins exhibit excess flow deviation in relation to the 
Table 4 Changes to precipitation $(\mathrm{P})$ and discharge $(\mathrm{Q})$ from 1961-1991 to 1991-2002 for 13 major Arctic basins (mm/year)

Positive values in the last column indicate excess discharge, in relation to precipitation

\begin{tabular}{lrrr}
\hline Basin & \multicolumn{1}{c}{$\Delta \mathrm{P}$} & \multicolumn{1}{c}{$\Delta \mathrm{Q}$} & $\Delta \mathrm{Q}-\Delta \mathrm{P}$ \\
\hline Churchill & -49.8 & -69.7 & -19.9 \\
Indigirka & -38.3 & -3.0 & 35.3 \\
Kolyma & -13.9 & -8.8 & 5.2 \\
Lena & -7.6 & 0.9 & 8.5 \\
Mackenzie & -32.1 & -3.4 & 28.7 \\
Nelson & -1.0 & 0.1 & 1.1 \\
Ob & 18.3 & 9.6 & -8.7 \\
Olenek & -2.7 & 80.7 & 83.4 \\
Pechora & 23.8 & 47.3 & 23.5 \\
S Dvina & 5.9 & 26.9 & 21.0 \\
Yana & -34.2 & 0.0 & 34.2 \\
Yenisey & 9.7 & 19.7 & 9.9 \\
Yukon & -26.7 & 16.6 & 43.3 \\
Average basin value & -11.4 & 9.0 & 20.4 \\
Area-weighted pan-Arctic average & -3.7 & 7.5 & 11.1 \\
\hline
\end{tabular}

precipitation deviation; that is, after the 1961-1990 climate period, discharge has increased more (or decreased less) than precipitation within each basin. These disagreements between precipitation and discharge deviations are in some cases large. At the same time, temperature has increased in the basins, which should lead to increased evapotranspiration and therefore less runoff, not more. Previous studies have indeed indicated that Arctic evapotranspiration has increased (Serreze et al. 2002; Park et al. 2008; Rawlins et al. 2010). Therefore, an essential question for forthcoming investigation is: where does the extra discharge water come from?

In the present synthesis, we note that the same question also arises from an integrated assessment of freshwater inflow to the Arctic Ocean (Dyurgerov et al. 2010). This assessment is in line with other studies, which also indicate an increase in freshwater inflow to the Arctic Ocean. However, the Dyurgerov et al. (2010) analysis further highlights that the magnitude of the increase in total flows from the 1961-1992 to the 1993-2006 period is similar for the Arctic river contributions $\left(87 \mathrm{~km}^{3} /\right.$ year $)$ as for the Arctic glacier contributions ( $56 \mathrm{~km}^{3} /$ year). Figure 6 shows a main implication of that result for sea-level rise, underlining the importance of also accounting for river discharge changes that are not related to glacial mass balance changes as a possible contributing source for sea-level rise and freshening of the Arctic Ocean. However, determining whether also the eustatic components of these increases are of similar magnitude requires further and more refined analysis and modeling.

\section{Results for Pan-Arctic Drainage Basin Monitoring}

The earlier comprehensive analysis of pan-Arctic hydrological and hydrochemical monitoring by Bring and Destouni (2009) has shown a considerable difference between accessible water chemistry monitoring and discharge monitoring. This difference concerns both the total extent and the characteristics of the data. In general, discharge data are 

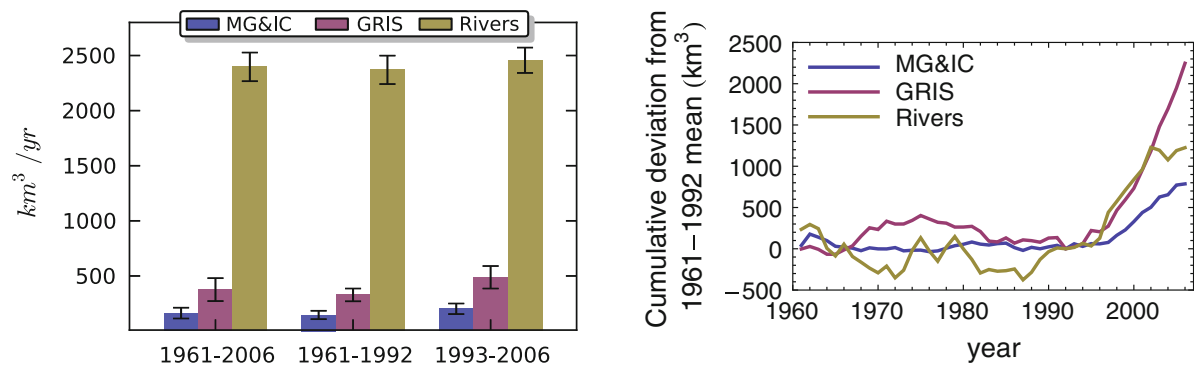

Fig. 6 Left Total meltwater runoff and total river runoff into the Arctic Ocean. Right Cumulative deviations in annual freshwater flows from mountain glaciers and ice caps (MG\&IC), Greenland ice sheet (GRIS), and rivers relative to average values for 1961-1992

available for a wide range of different hydrological basins, from small catchments of a few square kilometers in size to the major river basins in the PADB. In contrast, accessible data from water chemistry monitoring are limited to a much smaller set of stations, which cover a significantly smaller area and also a much less complete range of basin sizes.

Figure 7 summarizes the accessible length of time series for discharge, and waterborne sediment and carbon data in hydrologically monitored Arctic areas. The average length of the time series for the various parameters, and the corresponding share of the PADB that is monitored, is further summarized in Table 5.

Results from this analysis further show a marked difference in the characteristics of monitored and unmonitored areas (Fig. 8). For example, monitored areas are distinctly dominated by the taiga eco-region, while unmonitored areas are generally strongly defined by tundra-type vegetation. This tendency is particularly evident for discharge monitoring in all regions and for all monitoring parameters in Asia. The most balanced monitoring, in terms of eco-region proportions, is for carbon monitoring in Europe, while the most unbalanced monitoring is found in North America and Asia. Such regional monitoring differences complicate the interpretation of observation data differences between different parts of the PADB.

\section{Discussion}

Robust scientific understanding of climate and water systems requires access to relevant information on changes to flows of water and waterborne constituents. Gaps in understanding and unreliability in GCM projections imply, for example, that costly dimensioning decisions for infrastructure and buildings may be more or less risk-prone than expected from the model results, or that changes in agricultural, and food and water security conditions are not properly accounted for.

In this paper, we have aimed to contribute to a more complete picture of several of the central components required for AHC change assessment and adaptation planning at drainage basin scales. Specifically, we have investigated three overarching topics pertaining to the relevance of GCM projections for Arctic drainage basins, the understanding of hydro-climatic change in these basins beyond just precipitation and the spatiotemporal basin coverage of Arctic hydrological and hydrochemical monitoring systems. 


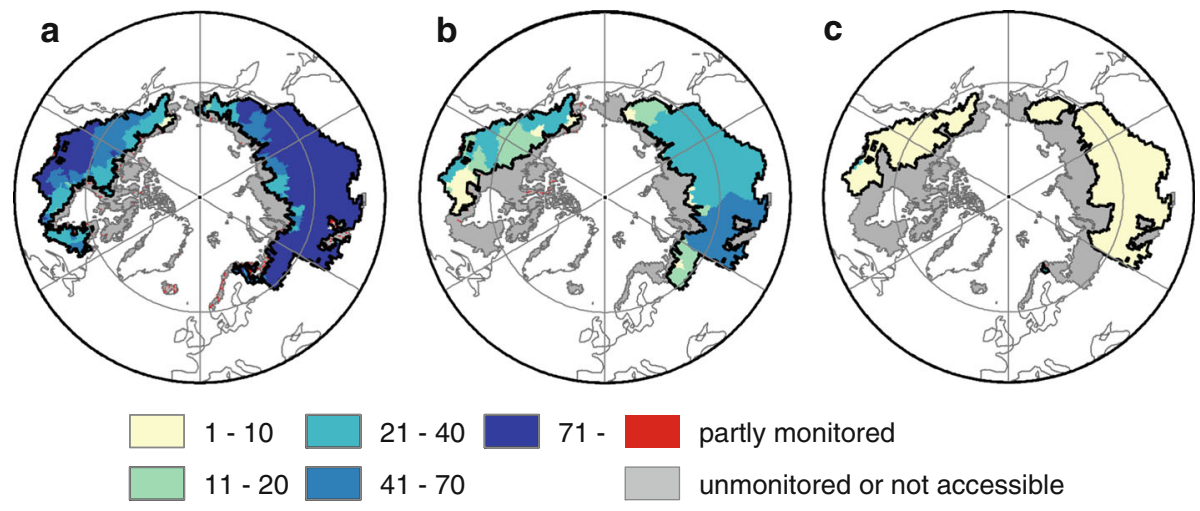

Fig. 7 Overview of the maximum length of accessible data series (years) for the pan-Arctic monitoring of a water discharge, $\mathbf{b}$ sediment and $\mathbf{c}$ carbon. Cells containing stations with drainage areas smaller than five cells are indicated as partly monitored

Table 5 Average length of time series and monitored share of total area for discharge, carbon and sediment data in the PADB

\begin{tabular}{lll}
\hline Parameters & $\begin{array}{l}\text { Average time series } \\
\text { length (years) }\end{array}$ & $\begin{array}{l}\text { Area } \\
\text { monitored (\%) }\end{array}$ \\
\hline Discharge & 29 & 73 \\
Sediment & 7 & 63 \\
Carbon & 5 & 51 \\
\hline
\end{tabular}
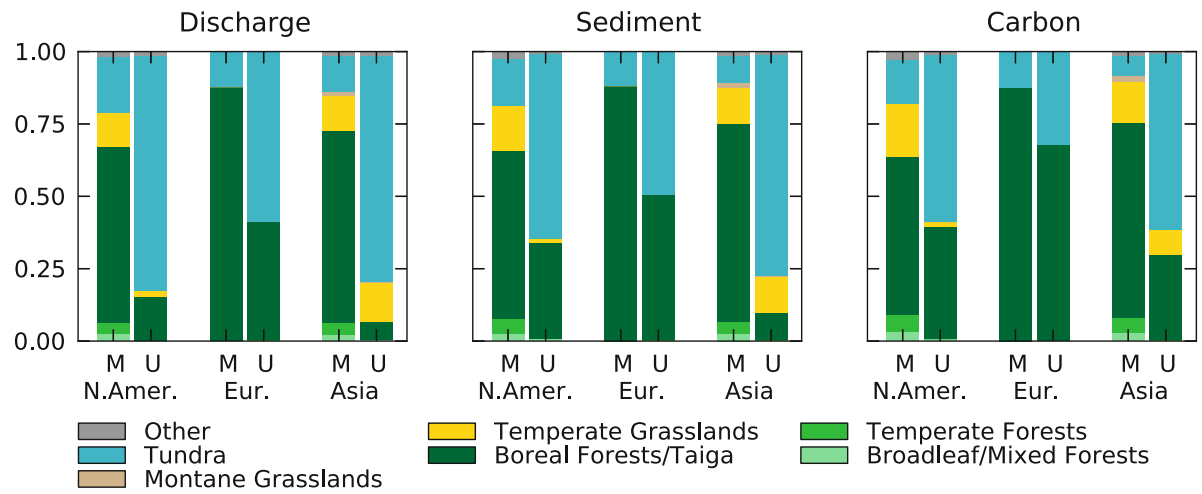

Fig. 8 Distribution of terrestrial eco-regions in monitored (M) and unmonitored (U) areas, by monitoring parameter and continent

\subsection{GCM Projections Across Arctic Basins}

Regarding the first investigation topic, on the relevance of GCM projections, the results highlight the improvements in basin-scale climate model simulation of temperature and precipitation between the TAR and AR4 generation of GCMs. However, the analysis also identifies some remaining limitations in precipitation simulations. 
Considerable advances have been made between the two successive generations of model ensemble runs that underlie the latest available full IPCC Assessment Reports, the TAR and the AR4. Examples include improved parameterization of land surface schemes and snowpack, as well as the inclusion of canopy processes in most models (Randall et al. 2007). However, remaining uncertainties include the representation of cryospheric feedbacks, which explain part of the range of model responses at mid- and high latitudes (Randall et al. 2007).

These improvements are suggested by the fact that the results indicate a lower spread among the ensemble members for the AR4 models and, in the case of precipitation, a marked improvement in the agreement with absolute observed values. However, despite the improvement in precision, accuracy remains insufficient for precipitation projections, which, even if they were correct, are still difficult to translate to subsequent changes in the water cycle without further and finer resolved hydrological modeling. The uncertainty in observations, particularly gauge undercatch of solid precipitation due to wind (e.g., Yang et al. 2005; Tian et al. 2007), may explain part of the remaining difference between observations and the improved AR4 results.

The large span in model performance, evident from the explicit error and performance analysis of AR4 models, also indicates that large uncertainties and shortcomings remain for reliable simulations of hydro-climatic parameters on basin scales. The analysis furthermore underlines that models may yield good output results on these scales for the wrong reasons. For example, the pan-Arctic bias error (MBE) of temperature for the GIER model is close to zero. This would place it at the top of a basin-scale simulation performance ranking based on this measure. At the same time, the absolute error (MAE) and the performance index $\left(d_{r}\right)$ for the same model are among the worst of the ensemble, implying large deviations from observations at individual grid points, even though the deviations happen to almost cancel out across the PADB.

The results for climate deviation and change severity across different basins further indicate that the relative distribution of climate change simulated by AR4 GCM projections does not agree with the relative distribution of currently observed climate deviations across the major Arctic basins. This complicates the choice of a robust prioritization strategy for hydrological monitoring development based on the reconciliation of observations and projections for the assessment of which Arctic river basins that are/will be most affected by climate change; this complication is further discussed in Sect. 6.3.

\subsection{Arctic Hydro-Climatic Change}

In the Arctic, certain counterintuitive hydro-climatic changes have caused extensive investigation and discussion in the scientific community. The fact that most of the 13 major rivers we study can be termed so-called excess rivers (i.e., the increase in discharge has been greater than the increase in precipitation) is consistent with findings by Milliman et al. (2008) for a related set of Arctic rivers. This and other studies (e.g., Dyurgerov and Carter 2004; McClelland et al. 2006; Smith et al. 2007; Lyon et al. 2009; Brutsaert and Hiyama 2012) indicate that both specific climatic and subsurface processes pertaining to the Arctic, such as permafrost degradation, as well as other anthropogenic changes and general atmospheric patterns, including increased moisture transport from outside the PADB, are responsible for the range in discharge patterns. Changes in glacier mass balance cannot explain the results of increasing river flows as the vast majority of Arctic glacier area and volume is located outside the major river basins (Dyurgerov et al. 2010). However, the relative importance of the different contributing factors is not definitely established. 
Undercatch of snow, in combination with increases in winter precipitation (Bulygina et al. 2009; Rawlins et al. 2009), is also a potential contributing factor.

The wide spread in discharge responses to precipitation changes indicates a need for further concerted modeling and field investigation efforts aimed at increasing the process knowledge of hydrological regimes particular to the Arctic domain, including the simulations of evapotranspiration and permafrost processes, considering also the effects of scale (Rennermalm et al. 2012). Improved parameterization, in particular with precipitation focus, is also critical to the development of GCMs, and continued water-balance assessments and closure experiments in Arctic catchments are motivated.

The extended water budget change over the entire PADB and its drainage into the Arctic Ocean, including glacier contributions, also has implications for the global climate system. The fact that the increase in the river freshwater contribution is of the same order of magnitude as the increase in meltwater from MG\&IC or from GRIS underlines the importance of better understanding the reasons for the river flow changes, and the potentially contributing components of frozen and liquid water storage changes in major Arctic basins (e.g., Muskett and Romanovsky 2009). Such changes could have large implications for the pan-Arctic hydro-climatic system, for example, through ground subsidence from permafrost degradation and/or altered soil moisture conditions, but also beyond the Arctic through contribution to sea-level rise and thermohaline circulation.

\subsection{Pan-Arctic Drainage Basin Monitoring}

The analysis of hydrological and hydrochemical data accessibility points to some major shortcomings, but also to opportunities and results of relevance for future research and monitoring improvements.

The synthesis of monitoring data shows a particular lack of water chemistry data, whereas discharge data are more extensively accessible. The range of spatial monitoring coverage, sampling frequency and length of time series for water chemistry data overall compare negatively with the corresponding attributes for discharge data. Together, these shortcomings imply that the full potential of translating existing discharge data to also calculate mass fluxes of biogeochemically important water constituents is hindered.

Furthermore, the difference in characteristics of hydrologically monitored areas evident from this analysis shows that existing monitoring data are not representative of the PADB as a whole. This constitutes a limitation to the input/validation data, and thereby also to reliability of the modeling that must be used to interpret and project $\mathrm{AHC}$ changes in unmonitored areas. It also limits the ability to improve GCM parameterizations and land surface schemes for the region, due to the lack of data to establish a ground truth to compare with.

From the perspective of an integrative pan-Arctic analysis, the limited accessibility to water chemistry data is remarkable, given the high profile of and international commitment to research into Arctic environmental changes. While discharge data have been compiled into pan-Arctic data sets [most importantly, R-ArcticNET (Lammers et al. 2001) and the ARDB (http://ardb.bafg.de)] and also made accessible in near real time through the ArcticRIMS project (http://rims.unh.edu), water chemistry data remain fragmented, although the recent continuation of the PARTNERS project as the Arctic Great Rivers Observatory (http://www.arcticgreatrivers.org) constitutes a substantial improvement.

Several factors may explain these results. Firstly, although the research community emphasizes a system perspective on the pan-Arctic domain, no international body has formal responsibility for an integrated water monitoring system. Instead, monitoring efforts 
must build upon undertakings by separate government agencies in at least the eight different nations of the Arctic Council, and for hydrology also Mongolia and Kazakhstan, which constitute parts of the PADB. Even if all national hydrometeorological agencies were committed to promoting a coordinated Arctic observation effort, domestic budget limitations and conflicting information goals may still interfere with ambitions being met.

Secondly, public agencies that apply cost-recovery principles to their environmental data may be reluctant to undermine this rule by freely sharing their data with international repositories. Thirdly, in a previously isolated Arctic that is now rapidly becoming more accessible to activities such as natural resource exploration, shipping and tourism, water data may be viewed as increasingly sensitive information from both political and economic perspectives. Occasionally, pressure from international organizations on member states to disclose water chemistry information viewed as sensitive has rebounded and instead caused delays in the progress of sharing other water data (Vladimir Ryabinin, personal communication).

Despite these potential obstacles, member states of the Arctic Council have in the Troms $\varnothing$ Declaration recently committed to facilitate data access. The organizational form for this commitment is the Sustaining Arctic Observation Networks (SAON) process, which is currently in its implementation phase. The European Commission has also expressed support for SAON (European Commission 2008, 2012). It remains to be seen to which extent the SAON process can contribute to increased accessibility to monitored water chemistry data in the PADB, but it is now established as a platform for policy dialog on Arctic monitoring issues, for example, through recurring Arctic Observation Summits.

To improve monitoring systems while considering climate change, and with limited resources, one must develop a strategy to decide which areas that should be prioritized. If GCM projections and observations were in agreement on which basins that are the most affected by climate change, a natural prioritization basis would be the rank of these basins by their relative intensity of change. However, the results in this study show that projections and observations diverge in this regard.

An alternative strategy may be to instead prioritize basins where the disagreement between observations and projections is particularly large, as such a strategy would yield important information on the hydro-climatic system functioning and changes regardless of whether there is actual convergence of observations and projections in the end or not. Alternatively, one could argue for prioritizing monitoring of basins with greater observed deviations so far, as these are based on the actual measurements, and increased efforts at understanding and adapting to them can be intrinsically motivated. With respect to precipitation deviations, such a prioritization is to some degree evident in the present distribution of monitoring (greater observed deviations correlate with greater monitoring effort), although this situation is most likely by coincidence rather than by design.

Based on the results in this study, one can thus argue for different rationales and prioritization bases when planning for increased hydro-climatic monitoring efforts under climate change conditions. These different rationales and prioritization bases point in diverging directions, which underlines the importance of attempting to formulate win-win or no-regret solutions (UNECE 2009) that also incorporate other parameters, in addition to temperature and precipitation outputs of climate models, and to explicitly formulate water information goals to be achieved. The results presented here can inform observation assessments connected to strategic Arctic initiatives and programs, such as SAON and the upcoming Third International Conference on Arctic Research Planning (ICARP III) in 2015, where continued evaluation of monitoring efforts will be a priority. 


\subsection{General Discussion}

The review of literature and analysis in this paper confirms a picture of advances in our knowledge about the Arctic water environment and its functioning during recent decades. Climate model advances have improved in precision and alignment with observations in the Arctic, and numerous studies have contributed to a fuller understanding of hydroclimatic changes. International efforts at making discharge information accessible, e.g., through the ArcticRIMS project, have contributed to a more timely access to river flow data for a number of the major Arctic basins and sub-basins. Similarly, the PARTNERS monitoring campaign (http://ecosystems.mbl.edu/partners), now semi-permanently established as the Arctic Great Rivers Observatory (http://www.arcticgreatrivers.org), has provided a multi-season data set of concentrations of a range of biogeochemical water chemistry constituents for six major Arctic rivers. These developments, which coincide in time with a growing focus on the Arctic as a place of large-scale geophysical and geopolitical changes, imply that our ability to understand the AHC has increased.

Nevertheless, considerable challenges for understanding and managing the rapidly changing Arctic water system still remain. A critical priority must be to continue improving the accessibility to water data, in particular for water chemistry, for the PADB. Observations must be made at well-chosen places, with the choices and improvements being based on clearly stated information goals, striving in their achievement for win-win and no-regret approaches that do not rely on some single, most likely model scenario of future hydro-climatic conditions. Improved coverage of unmonitored areas in the northern rims of the PADB is also motivated, particularly as these areas are expected to become increasingly accessible and also subject to exploration with a warming climate (Andreeva 1998). In addition, improved monitoring here may provide better insight into the total flux of water constituents to the ocean from these areas, as near-ocean catchments have in other regions been shown to contribute a disproportionately large share of coastal pollution in relation to the drainage basin as a whole (Destouni et al. 2008).

\section{Conclusions}

In this paper, we have synthesized and investigated climate model projections, hydroclimatic change understanding and adequacy of water flow and water chemistry observations in the PADB. The purpose has been to establish a quantitative picture of the status of model results, hydro-climatic links and observations needed to understand and manage water cycle changes in the Arctic. The main findings of the paper can be summarized in the following conclusions:

- The precision in climate model projection of precipitation and temperature change on drainage basin scales has improved between successive generations of the IPCC model ensemble. Individual model performance varies greatly, and models can be right for the wrong reasons when relatively large errors cancel out on large basin scales for some models. Further investigation and benchmarking of model performance in the GCMs that underlie the IPCC AR5 will show whether certain hydro-climatological model shortcomings in the Arctic have been addressed.

- From the investigation into geographical consistency in the relative distribution of climate deviations and changes, it follows that establishing regional priorities for hydrological monitoring systems, with regard to the specific issue of climate changes in 
the Arctic, can currently not be achieved based solely on a reconciliation of observations and projections. When taking different data and system/change perspectives as starting points, different conclusions about what constitutes rational monitoring priorities, and related strategies, arise.

- Hitherto observed deviations in precipitation do not translate into similar deviations in discharge even over the large scales of the 13 studied basins. The discrepancy between precipitation and discharge deviations, and the fact that this discrepancy principally is expressed as excess in discharge compared to available precipitation, indicates that a component of the discharge variation may be due to changes in permafrost or groundwater storage. Potentially, these storage changes may also be a factor in the general deviations between observations and GCM simulations noted above.

- Even though the increase in river inflow to the Arctic Ocean during 1993-2006 is small in relative terms compared to the average flow for 1961-1992, in absolute terms it is of the same order of magnitude as the meltwater increase from glaciers. As the river flow changes are independent of the glacier contributions studied here, this underlines the importance of also accounting for river discharge changes as a potentially contributing source for sea-level rise and Arctic Ocean freshening.

- There is a lack of long-term and accessible water chemistry data for large parts of the PADB, and discharge data are also limited for considerable areas. The data that are accessible do not constitute a representative sample of the whole PADB environment.

Acknowledgments The research in this paper has been funded through grants from the Swedish research council Formas (Project Number 2007-1263) and the Swedish Research Council (VR; Project Number 2007-8393), and has been linked to the Bolin Centre for Climate Research (in turn supported by VR and Formas through a Linnaeus grant) and the strategic research project EkoKlim at Stockholm University. The study was inspired by and written for the documentation of the ISSI conference on The Earth's hydrological cycle, Bern, Switzerland, February 6-10, 2012.

Open Access This article is distributed under the terms of the Creative Commons Attribution License which permits any use, distribution, and reproduction in any medium, provided the original author(s) and the source are credited.

\section{References}

Adam JC, Lettenmaier DP (2003) Adjustment of global gridded precipitation for systematic bias. J Geophys Res 108:1-14

Adam JC, Clark EA, Lettenmaier DP, Wood EF (2006) Correction of global precipitation products for orographic effects. J Clim 19:15-38

Andreeva EN (1998) The Russian Arctic coastal zone management problems: past lessons and new realities. Ocean Coast Manag 41:237-256

Arctic-HYDRA consortium (2010) The Arctic hydrological cycle monitoring, modelling and assessment programme: Science and implementation plan. ISBN 978-9979-9975-0-4

Azcárate J, Balfors B, Bring A, Destouni G (2013) Strategic environmental assessment and monitoring: Arctic key gaps and bridging pathways. Environ Res Lett 8:044033

Boé J, Hall A, Qu X (2009) Current GCMs' unrealistic negative feedback in the Arctic. J Clim 22:4682-4695

Box JE, Bromwich DH, Veenhuis BA, Bai L-S, Stroeve JC, Rogers JC, Steffen K, Haran T, Wang S-H (2006) Greenland ice sheet surface mass balance variability (1988-2004) from calibrated Polar MM5 output. J Clim 19:2783-2800

Bring A, Destouni G (2009) Hydrological and hydrochemical observation status in the pan-Arctic drainage basin. Polar Res 28:327-338 
Bring A, Destouni G (2011) Relevance of hydro-climatic change projection and monitoring for assessment of water cycle changes in the Arctic. Ambio 40:361-369

Bring A, Destouni G (2013) Hydro-climatic changes and their monitoring in the Arctic: observation-model comparisons and prioritization options for monitoring development. J Hydrol 492:273-280

Brown K (2002) Water scarcity: forecasting the future with spotty data. Science 297:926-927

Brown R, Derksen C, Wang L (2010) A multi-data set analysis of variability and change in Arctic spring snow cover extent, 1967-2008. J Geophys Res 115:D16111

Brutsaert W, Hiyama T (2012) The determination of permafrost thawing trends from long-term streamflow measurements with an application in eastern Siberia. J Geophys Res 117:D22110

Bulygina ON, Razuvaev VN, Korshunova NN (2009) Changes in snow cover over Northern Eurasia in the last few decades. Environ Res Lett 4:045026

Callaghan TV, Johansson M, Brown RD, Groisman PY, Labba N, Radionov V, Barry RG, Bulygina ON, Essery RLH, Frolov DM, Golubev VN, Grenfell TC, Petrushina MN, Razuvaev VN, Robinson DA, Romanov P, Shindell D, Shmakin AB, Sokratov SA, Warren S, Yang D (2011) The changing face of Arctic snow cover: a synthesis of observed and projected changes. Ambio 40:17-31

Christensen JH, Hewitson B, Busuioc A, Chen A, Gao X, Held I, Jones R, Kolli RK, Kwon W-T, Laprise R, Magaña Rueda V, Mearns L, Menéndez CG, Räisänen J, Rinke A, Sarr A, Whetton P (2007) Regional climate projections. In: Solomon S, Qin D, Manning M, Chen Z, Marquis M, Averyt KB, Tignor M, Miller HL (eds) Climate change 2007: the physical science basis. Contribution of working group I to the fourth assessment report of the intergovernmental panel on climate change. Cambridge University Press, Cambridge

Comiso JC, Parkinson CL, Gersten R, Stock L (2008) Accelerated decline in the Arctic sea ice cover. Geophys Res Lett 35:L01703

Darracq A, Lindgren G, Destouni G (2008) Long-term development of phosphorus and nitrogen loads through the subsurface and surface water systems of drainage basins. Global Biogeochem Cycles 22:GB3022

Destouni G, Hannerz F, Prieto C, Jarsjö J, Shibuo Y (2008) Small unmonitored near-coastal catchment areas yielding large mass loading to the sea. Global Biogeochem Cycles 22:GB4003

Destouni G, Jaramillo F, Prieto C (2013) Hydroclimatic shifts driven by human water use for food and energy production. Nat Clim Chang 3:213-217

Dyurgerov MB, Carter CL (2004) Observational evidence of increases in freshwater inflow to the Arctic Ocean. Arct Antarct Alp Res 36:117-122

Dyurgerov MB, Meier MF (2005) Glaciers and the changing Earth system: a 2004 snapshot. Occasional Paper 58. Institute of Arctic and Alpine Research, Boulder, Colorado, pp 117

Dyurgerov MB, Bring A, Destouni G (2010) Integrated assessment of changes in freshwater inflow to the Arctic Ocean. J Geophys Res 115:D12116

Eisenman I, Untersteiner N, Wettlaufer JS (2007) On the reliability of simulated Arctic sea ice in global climate models. Geophys Res Lett 34:L10501

Environment Canada (2004) HYDAT version 2004-20.04. Water Survey of Canada, Ottawa

European Commission (2008) Communication from the commission to the European parliament and the council-the European union and the Arctic region. COM 763

European Commission (2012) The inventory of activities in the framework of developing a European Union Arctic Policy. Joint Staff Working Document 182

FAO (2009) UN-Water task force on indicators, monitoring and reporting final report. Monitoring progress in the water sector: a selected set of indicators. Food and Agriculture Organization of the United Nations, Rome

Fekete BM, Vörösmarty CJ (2002) The current status of global river discharge monitoring and potential new technologies complementing traditional discharge measurements. In: Predictions in Ungauged Basins: PUB Kick-off (Proceedings of the PUB Kick-off meeting held in Brasilia, 20-22 November 2002). IAHS Publication 349. International Association of Hydrological Sciences, Paris

Fluctuations of Glaciers (FoG) 2000-2005 (2008) ICSU(CCS)-UNEP-UNESCO 2008, vol IX. World Glacier Monitoring Service, Zürich

Gardner AS, Moholdt G, Wouters B, Wolken GJ, Burgess DO, Sharp MJ, Cogley JG, Braun C, Labine C (2011) Sharply increased mass loss from glaciers and ice caps in the Canadian Arctic Archipelago. Nature 473:357-360

GEO (2010) The GEO Beijing declaration: Observe, share, inform. Beijing ministerial summit document. Group on Earth Observations, Geneva

Glazovsky AF, Macheret YY (2006) Evraziyskaya Arktika. In: Kotlyakov VM (ed) Oledenenie Evrazii v proshlom, nastoyashchem i blizhayshem budushchem, vol 1. Nauka, Moscow, pp 97-114 
Hanna E, Huybrechts P, Steffen K, Cappelen J, Huff R, Shuman C, Irvine-Fynn T, Wise S, Griffits M (2008) Increased runoff from melt from the Greenland ice sheet: a response to global warming. J Clim 21:331-341. doi:10.1175/2007JCLI1964.1

Hanna E, Cappelen J, Fettweis X, Huybrechts P, Luckman A, Ribergaard MH (2009) Hydrologic response of Greenland ice sheet: The role of oceanographic warming. Hydrol Process 23. doi:10.1002/hyp.7090

Hannerz F (2008) Making water information relevant on local to global scale-the role of information systems for integrated water management. PhD thesis. Stockholm University, Sweden

Harris I, Jones PD, Osborn TJ, Lister DH (2013) Updated high-resolution grids of monthly climatic observations - the CRU TS3.10 dataset. Int J Climatol. doi:10.1002/joc.3711

Hinzman LD, Bettez ND, Bolton WR, Chapin FS, Dyurgerov MB, Fastie CL, Griffith B, Hollister RD, Hope A, Huntington HP, Jensen AM, Jia GJ, Jorgenson T, Kane DL, Klein DR, Kofinas G, Lynch AH, Lloyd AH, McGuire AD, Nelson FE, Oechel WC, Osterkamp TE, Racine CH, Romanovsky VE, Stone RS, Stow DA, Sturm M, Tweedie CE, Vourlitis GL, Walker MD, Walker DA, Webber PJ, Welker JM, Winker KS, Yoshikawa K (2005) Evidence and implications of recent climate change in northern Alaska and other Arctic regions. Clim Chang 72:251-298

Holland MM, Finnis J, Barrett AP, Serreze MC (2007) Projected changes in Arctic Ocean freshwater budgets. J Geophys Res 112. doi:10.1029/2006JG000354

Holland MM, Serreze MC, Stroeve J (2010) The sea ice mass budget of the Arctic and its future change as simulated by coupled climate models. Clim Dyn 34:185-200

Holmes RM, Peterson BJ (2002) Eurasian river historical nutrient and sediment flux data. Digital media. National Snow and Ice Data Center, Boulder, Colorado

Holmes RM, Peterson BJ, Gordeev VV, Zhulidov AV, Meybeck M, Lammers RB, Vörösmarty CJ (2000) Flux of nutrients from Russian rivers to the Arctic Ocean: can we establish a baseline against which to judge future changes? Water Resour Res 36:2309-2320

Holmes RM, Makkaveev PN, Stunzhas PA, Kosmenko LS, Köhler GH, Shiklomanov AI (2001) Nutrient chemistry of the $\mathrm{Ob}$ and Yenisey rivers, Siberia: results from June 2000 expedition and evaluation of long-term data sets. Mar Chem 75:219-227

Holmes RM, McClelland JW, Peterson BJ, Shiklomanov IA, Shiklomanov AI, Zhulidov AV, Gordeev VV, Bobrovitskaya NN (2002) A circumpolar perspective on fluvial sediment flux to the Arctic Ocean. Global Biogeochem Cycles 16:1098

Hurrell JW, van Loon H (1997) Decadal variations in climate associated with the North Atlantic Oscillation. In: Climatic change at high elevation sites. Springer, Berlin, pp 69-94

ICSU (2010) Earth system science for global sustainability: The grand challenges. International Council for Science, Paris

Karlsson JM, Bring A, Peterson GD, Gordon LJ, Destouni G (2011) Opportunities and limitations to detect climate-related regime shifts in inland Arctic ecosystems through eco-hydrological monitoring. Environ Res Lett 6:014015

Kaser G, Cogley JG, Dyurgerov MB, Meier MF, Ohmura A (2006) Mass balance of glaciers and ice caps: consensus estimates for 1961-2004. Geophys Res Lett 33:L19501

Kattsov VM, Källén E, Cattle H, Christensen J, Drange H, Hanssen-Bauer I, Jóhannesen T, Karol I, Räisänen J, Svensson G, Vavulin S, Chen D, Polyakov I, Rinke A (2005) Future climate change: modeling and scenarios for the Arctic. In: Arctic climate impact assessment. Cambridge University Press, Cambridge, pp 99-150

Kattsov VM, Walsh JE, Chapman WL, Govorkova VA, Pavlova TV, Zhang X (2007) Simulation and projection of Arctic freshwater budget components by the IPCC AR4 global climate models. J Hydrometeorol 8:571-589

Lammers RB, Shiklomanov AI, Vörösmarty CJ, Fekete BM, Peterson BJ (2001) Assessment of contemporary Arctic river runoff based on observational discharge records. J Geophys Res 106:3321-3334

Lui J, Zhang Z, Hu Y, Chen L, Dai Y, Ren X (2008) Assessment of surface air temperature over the Arctic Ocean in reanalysis and IPCC AR4 model simulations with IABP/POLES observations. J Geophys Res 113:D10105

Lyon SW, Destouni G (2010) Changes in catchment-scale recession flow properties in response to permafrost thawing in the Yukon river basin. Int J Climatol 30. doi:10.1002/joc.1993

Lyon SW, Destouni G, Giesler R, Humborg C, Mörth M, Seibert J, Karlsson J, Troch PA (2009) Estimation of permafrost thawing rates in a sub-Arctic catchment using recession flow analysis. Hydrol Earth Syst Sci 13:595-604

Lyon S, Morth M, Humborg C, Giesler R, Destouni G (2010) The relationship between subsurface hydrology and dissolved carbon fluxes for a sub-arctic catchment. Hydrol Earth Syst Sci 14:941-950 
Mächel H, Rudolf B, Maurer T, Hagemann S, Hagenbrock R, Kitaev L, Førland EJ, Rasuvaev V, Tveito OE (2012) Observed hydrological cycle. In: Lemke P, Jacobi H-W (eds) Arctic climate change: the ACSYS decade and beyond, Springer, Berlin, pp 199-246

Maurer T (2003) Development of an operational internet-based near real time monitoring tool for global river discharge data. GRDC Report 30. Global Runoff Data Centre, Koblenz

McBean G, Alekseev G, Chen D, Foerland E, Fyfe J, Groisman PY, King R, Melling H, Vose R, Whitfield PH (2005) Arctic climate: past and present. In: Arctic climate impact assessment. Cambridge University Press, Cambridge, pp 21-60

McClelland JW, Déry SJ, Peterson BJ, Holmes RM, Wood EF (2006) A pan-Arctic evaluation of changes in river discharge during the latter half of the 20th century. Geophys Res Lett 33:L06715

McClelland JW, Holmes RM, Peterson BJ, Amon R, Brabets T, Cooper L, Gibson J, Gordeev VV, Guay C, Milburn D, Staples R, Raymond PA, Shiklomanov I, Striegl R, Zhulidov A, Gurtovaya T, Zimov S (2008) Development of a pan-Arctic database for river chemistry. EOS Trans Am Geophys Union 89. doi:10.1029/2008EO240001

McGuire AD, Chapin FS, Walsh JE, Wirth C (2006) Integrated regional changes in Arctic climate feedbacks: implications for the global climate system. Annu Rev Environ Resour 31:61-91

Mernild SH, Liston GE, Hiemestra CA, Steffen K, Hanna E, Christensen JH (2009) Greenland ice sheet surface mass-balance modeling and freshwater flux for 2007, and in a 1995-2007 perspective. Hydrol Process 23. doi:10.1002/hyp.7354

Milliman J, Farnsworth K, Jones P, Xu K, Smith L (2008) Climatic and anthropogenic factors affecting river discharge to the global ocean, 1951-2000. Global Planet Change 62:187-194

Mitchell TD, Jones PD (2005) An improved method of constructing a database of monthly climate observations and associated high-resolution grids. Int J Climatol 25:693-712

Mueller B, Seneviratne SI, Jimenez C, Corti T, Hirschi M, Balsamo G, Ciais P, Dirmeyer P, Fisher JB, Guo Z, Jung M, Maignan F, McCabe MF, Reichle R, Reichstein M, Rodell M, Sheffield J, Teuling AJ, Wang K, Wood EF, Zhang Y (2011) Evaluation of global observations-based evapotranspiration datasets and IPCC AR4 simulations. Geophys Res Lett 38:L06402

Muskett RR, Romanovsky VE (2009) Groundwater storage changes in arctic permafrost watersheds from GRACE and in situ measurements. Environ Res Lett 4:045009

Nilsson LM, Destouni G, Berner J, Dudarev AA, Mulvad G, Odland JO, Parkinson A, Tikhonov C, Rautio A, Evengård B (2013) A call for urgent monitoring of food and water security based on relevant indicators for the Arctic. Ambio 42. doi:10.1007/s13280-013-0427-1

Overeem I, Syvitski JPM (2010) Shifting discharge peaks in Arctic rivers, 1977-2007. Geografiska Ann Ser A Phys Geogr 92:285-296

Overland JE, Wang M (2007) Future regional Arctic sea ice declines. Geophys Res Lett 34:L17705

Pahl-Wostl C (2007) Transitions towards adaptive management of water facing climate and global change. Water Resour Manage 21:49-62

Palmer MA, Lettenmaier DP, Poff NL, Postel SL, Richter B, Warner R (2009) Climate change and river ecosystems: protection and adaptation options. Environ Manage 44:1053-1068

Park H, Yamazaki T, Yamamoto K, Ohta T (2008) Tempo-spatial characteristics of energy budget and evapotranspiration in the eastern Siberia. Agric For Meteorol 148:1990-2005

Peterson BJ, Holmes RM, McClelland JW, Vörösmarty CJ, Lammers RB, Shiklomanov AI, Shiklomanov IA, Rahmstorf S (2002) Increasing river discharge to the Arctic Ocean. Science 298:2171-2173

Peterson BJ, McClelland J, Curry R, Holmes RM, Walsh JE, Aagaard K (2006) Trajectory shifts in the Arctic and subarctic freshwater cycle. Science 313:1061-1066

Randall DA, Wood RA, Bony S, Colman R, Fichefet T, Fyfe J, Kattsov V, Pitman A, Shukla J, Srinivasan J, Stouffer RJ, Sumi A, Taylor KE (2007) Climate models and their evaluation. In: Solomon S, Qin D, Manning M, Chen Z, Marquis M, Averyt KB, Tignor M, Miller HL (eds) Climate change 2007: The physical science basis. Contribution of working group I to the fourth assessment report of the intergovernmental panel on climate change. Cambridge University Press, Cambridge

Rawlins MA, Ye H, Yang D, Shiklomanov A, McDonald KC (2009) Divergence in seasonal hydrology across northern Eurasia: emerging trends and water cycle linkages. J Geophys Res 114:D18119

Rawlins MA, Steele M, Holland MM, Adam JC, Cherry JE, Francis JA, Groisman PY, Hinzman LD, Huntington TG, Kane DL, Kimball JS, Kwok R, Lammers RB, Lee CM, Lettenmaier DP, McDonald KC, Podest E, Pundsack JW, Rudels B, Serreze MC, Shiklomanov A, Skagseth O, Troy TJ, Vörösmarty CJ, Wensnahan M, Wood EF, Woodgate R, Yang D, Zhang K, Zhang T (2010) Analysis of the Arctic system for freshwater cycle intensification: observations and expectations. J Clim 23:5715-5737

Raymond PA, McClelland JW, Holmes RM, Zhulidov AV, Mull K, Peterson BJ, Striegl RG, Aiken GR, Gurtovaya TY (2007) Flux and age of dissolved organic carbon exported to the Arctic Ocean: a carbon isotopic study of the five largest Arctic rivers. Global Biogeochem Cycles 21:GB4011 
Reid W, Chen D, Goldfarb L, Hackmann H, Lee Y, Mokhele K, Ostrom E, Raivio K, Rockström J, Schellnhuber H, Whyte A (2010) Earth system science for global sustainability: grand challenges. Science 330:916-917

Rennermalm AK, Bring A, Mote TL (2012) Spatial and scale-dependent controls on North American panArctic minimum river discharge. Geogr Anal 44:202-218

Rignot E, Box JE, Burgess E, Hanna E (2008) Mass balance of the Greenland ice sheet from 1958 to 2007. Geophys Res Lett 35:L20502. doi:10.1029/2008GL035417

Roesch A (2006) Evaluation of surface albedo and snow cover in AR4 coupled climate models. J Geophys Res 111:D15111

Seitz NE, Westbrook CJ, Dubé MG, Squires AJ (2013) Assessing large spatial scale landscape change effects on water quality and quantity response in the lower Athabasca River Basin. Integr Environ Assess Manag 9. doi:10.1002/ieam.1336

Serreze MC, Clark MP, Etringer AJ, Zhang T, Bromwich DH, Lammers R (2002) The large-scale hydroclimatology of the terrestrial Arctic drainage system. J Geophys Res 107. doi:10.1029/2001JD000919

Serreze MC, Barrett AP, Slater AG, Woodgate RA, Aagaard K, Lammers RB, Steele M, Moritz R, Meredith M, Lee CM (2006) The large-scale freshwater cycle of the Arctic. J Geophys Res 111. doi:10.1029/ 2005JC003424

Shiklomanov AI, Lammers RB (2009) Record Russian river discharge in 2007 and the limits of analysis. Environ Res Lett 4:045015

Shiklomanov AI, Lammers RB, Vörösmarty CJ (2002) Widespread decline in hydrological monitoring threatens pan-Arctic research. EOS Trans Am Geophys Union 83:13-17

Slater AG, Bohn TJ, McCreight JL, Serreze MC, Lettenmaier DP (2007) A multimodel simulation of panArctic hydrology. J Geophys Res 112:G04S45

Smith LC, Pavelsky TM, MacDonald GM, Shiklomanov AI, Lammers RB (2007) Rising minimum daily flows in northern Eurasian rivers: a growing influence of groundwater in the high-latitude hydrologic cycle. J Geophys Res 112:G04S47

Smol JP, Wolfe AP, Birks HJB, Douglas MSV, Jones VJ, Korhola A, Pienitz R, Rühland K, Sorvari S, Antoniades D, Brooks SJ, Fallu M-A, Hughes M, Keatley BE, Laing TE, Michelutti N, Nazarova L, Nyman M, Paterson AM, Perren B, Quinlan R, Rautio M, Saulnier-Talbot É, Siitonen S, Solovieva N, Weckström J (2005) Climate-driven regime shifts in the biological communities of Arctic lakes. Proc Natl Acad Sci 102:4397-4402

Sorteberg A, Kattsov V, Walsh J, Pavlova T (2007) The Arctic surface energy budget as simulated with the IPCC AR4 AOGCMs. Clim Dyn 29:131-156

Stroeve J, Holland MM, Meier W, Scambos T, Serreze M (2007) Arctic sea ice decline: faster than forecast. Geophys Res Lett 34:9501

Stroeve JC, Serreze MC, Holland MM, Kay JE, Malanik J, Barrett AP (2012a) The Arctic's rapidly shrinking sea ice cover: a research synthesis. Clim Chang 110:1005-1027

Stroeve JC, Kattsov V, Barrett A, Serreze M, Pavlova T, Holland M, Meier WN (2012b) Trends in Arctic sea ice extent from CMIP5, CMIP3 and observations. Geophys Res Lett 39:L16502

Tian X, Dai A, Yang D, Xie Z (2007) Effects of precipitation-bias corrections on surface hydrology over northern latitudes. J Geophys Res 112:D14101

UNECE (2009) Guidance on water and adaptation to climate change. United Nations Economic Commission for Europe, Geneva, p 144

Vörösmarty CJ, Hinzman LD, Peterson BJ, Bromwich DH, Hamilton LC, Morison J, Romanovsky VE, Sturm M, Webb RS (2001) The hydrologic cycle and its role in Arctic and global environmental change: A rationale and strategy for synthesis study. Arctic Research Consortium of the U.S., Fairbanks, Alaska, p 84

Walsh J, Anisimov O, Hagen JO, Jakobsson T, Oerlemans J, Prowse TD, Romanovsky V, Savelieva N, Serreze M, Shiklomanov A, Shiklomanov I, Solomon S (2005) Crysophere and hydrology. In: Arctic climate impact assessment. Cambridge University Press, Cambridge, pp 183-242

White D, Hinzman L, Alessa L, Cassano J, Chambers M, Falkner K, Francis J, Gutowski WJ, Holland M, Holmes RM, Huntington H, Kane D, Kliskey A, Lee C, McClelland J, Peterson B, Scott Rupp T, Straneo F, Steele M, Woodgate R, Yang D, Yoshikawa K, Zhang T (2007) The Arctic freshwater system: changes and impacts. J Geophys Res 112:G04S54

Willmott CJ, Robeson SM, Matsuura K (2012) A refined index of model performance. Int J Climatol 32. doi:10.1002/joc.2419

Yang D, Kane D, Zhang Z, Legates D, Goodison B (2005) Bias corrections of long-term (1973-2004) daily precipitation data over the northern regions. Geophys Res Lett 32:19

Zhang X, Walsh JE (2006) Toward a seasonally ice-covered Arctic Ocean: scenarios from the IPCC AR4 model simulations. J Clim 19:1730-1747 
Zhulidov AV, Khlobystov VV, Robarts RD, Pavlov DF (2000) Critical analysis of water quality monitoring in the Russian Federation and former Soviet Union. Can J Fish Aquat Sci 57:1932-1939

Zhulidov AV, Robarts RD, Holmes RM, Peterson BJ, Kämäri J, Meriläinen JJ, Headley JV (2003) Water quality monitoring in the former Soviet Union and the Russian Federation: Assessment of analytical methods. The Finnish Environment Report No. 620. Finnish Environment Institute, Helsinki 